\title{
Creativity and Creative Industries in Cairns: Views from the Field
}

\author{
Ryan Daniel
}

James Cook University

\begin{abstract}
The regional tropical city of Cairns, most well known as a major location for tourism, is also a vibrant creative place in northern Australia. Creativity and the creative industries in Cairns, however, have received little research attention since the turn of the $21^{\text {st }}$ century. Hence, this preliminary study seeks to explore key features of the sector and the participants involved. Survey data was initially obtained from a sample of 78 creative industries stakeholders, after which interviews were held with 20 of these participants to further explore key issues. The findings are significant and which reveal the creative qualities and strengths of the city and its region, a range of impediments to creativity, as well as numerous opportunities to grow the creative industries sector in Cairns.
\end{abstract}

$\mathrm{T}$ he creative industries and creative cities concepts are now well established in the discourse. While initially largely focused on urban localities and as a means by which to regenerate and grow metropolitan cities and economies (Waitt and Gibson 1223; Verdich 130; Luckman 2), there has been a recent shift to examine creativity beyond the city and towards regional or relatively isolated areas (Verdich 129). Place, regardless of location, is in fact increasingly seen as a contributor to creativity (Waitt and Gibson 1223). At the same time, while Drake agrees that "place can provide inspiration and a source of ideas for individual artists, designers, and musicians" (Drake 511), he is also of the view the creative industries policy and focus tends to obscure the relationship between individual creativity and place. According to Gibson, this issue is particularly relevant in Australia, given the geography of the country which features significant distances between a "few large cities" (Gibson 3) alongside numerous scattered and small towns. As this new discourse has emerged, it has led to views which suggest there is in fact a need to reconsider the creative industries rhetoric, or to at least better understand its relevance to contemporary creative life, given the creative class phenomenon espoused by urban studies theorists such as Richard Florida in the early 2000s has arguably failed to deliver on its much hyped promises (Kotkin n.p.).

Across its vast geography, Australia has many regional areas and cities or towns of small to medium size. Cairns is one of these, with a current population of approximately 130,000 and a high international profile as a consequence of its location beside the Great Barrier Reef and proximity to other natural wonders such as the Daintree wilderness, idyllic beaches and waterways. Tourism is therefore one of the dominant economies in Cairns (Welters, Stoeckl, Castorina and Daniel 3), indeed the location is "Australia's third most popular destination for international holiday visitors" (Invest Cairns n.p.). In terms of arts and cultural infrastructure, the city has various facilities that support creative practice (e.g. galleries, performing arts venues, outdoor spaces). Cairns also hosts significant art events, such as the Cairns Indigenous Arts Fair, Adventure film and Ukelele festivals among others. A range of independently run organisations facilitate creative practice, with representative groups across the disciplines of theatre, music, indigenous arts, visual arts and crafts. In terms of 
commercial creative practice, there are a number of service-oriented businesses, typically sole traders or small enterprises in the design/photomedia, marketing/advertising and/or digital media fields. While the city lacks the large-scale infrastructure of major Australian metropolitan centres, creativity and the creative industries are well represented within an active cultural community.

\section{Creativity in Regional Australia: Extant Research}

In recent years there has been a significant body of work to emerge in relation to creativity in the Australian regional context. Luckman refers to the fact that for non-urban creative workers, "an awareness of place is central to their creative practice and provides a profound practical and emotive link between their lives and their work" (3). In terms of this recent emergence of focus on regional issues and areas, the range of studies include those by:

- Brennan-Horley, Connell and Gibson (71) who considered how an Elvis revival festival in Parkes in regional New South Wales has led to contested notions of identity in that location;

- Waitt and Gibson (1243) who explore creative economy and creative place issues as applied to the regional city of Wollongong, recounting the largely failed attempts by civic leaders in attempting to transform the city through the creative class and creative cities approach;

- Lisa Anderson (71), who when investigating cultural industries in Broken Hill in far west New South Wales, discovered a range of enabling and disabling factors for those practicing as artists, with 'remoteness' offering creative inspiration but also causing many young artists to leave and current workers to have a sense of wariness of visitors and to change;

- Collis, Felton and Graham (110), who demonstrate that the current focus of creative industries policy on inner-city locations fails to account for the vibrancy and diversity of creative practice in such suburban locations as Redcliffe on the outskirts of Brisbane in Queensland; and

- Verdich who in interviewing 18 migrants to Launceston revealed that quality of life and lifestyle were key factors of influence, and in fact at odds to Florida's theory of 'scenes' and ' $24 / 7$ ' as key attractions, highlighting the importance of "appropriate and relevant economic development and promotion strategies, rather than taking a 'onesize-fits-all' approach" (139).

While there is an emerging area of research exploring creativity in non-urban areas, there remains a relatively limited body of work that specifically explores northern Australia. One exception is the recent and significant research by Brennan-Horley and Gibson (2595), Brennan-Horley, Luckman et al. (92), as well as Luckman, Gibson and Lea (70) in relation to Darwin's creative industries, this representing a major contribution to the literature and to understanding the intricacies of creative work and cultural practice in the most northern centre of Australia. In terms of far north Queensland and Cairns specifically, there is a limited body of work. Relevant studies include those by:

- Sallie Anderson (iv) who investigated the Aboriginal art industry in Cairns;

- Law (669) who explored the multi-racial history of Rusty's market and how it has helped shape the Cairns community; 
- Cole who explored music education in the Cairns region during the $20^{\text {th }}$ century, with a particular focus on the period between 1907-1970. In his body of work, Cole ("Aspects of Indigenous Music Education" 178; "Community Music" 82; "Tropical Sounds" 45) describes the tensions associated with informal and multi-cultural practices alongside formal and often imposed western practices in Schools, as well as highlighting a lack of research exploring indigenous music education practices and issues; and

- Youdell (3-4) who via interviews with over twenty key stakeholders relevant to the creative industries in Cairns, identified the fact that one of the key strengths for the city is its high profile internationally, although noted that specialist creative expertise is at times lacking and the sector more broadly has significant room for growth and development.

\section{The Creative Industries Focus: Relevance to Regional Locations?}

Initially emerging in government circles in such locations as the United Kingdom in the mid 1990s, since that time the creative industries concept - which focuses on intellectual property, markets and audiences - has spread globally as a means by which to grow developed and developing economies. Yet given it largely has a top-down or policy focus, alongside the fact that it represents an ideological and point of tension for many traditional artifact producers, its understanding and relevance to regional workers on the ground has been questioned (e.g. Luckman 2; Gibson 3). Indeed, Luckman refers to the fact it is an "identifier that is not embraced by all" (12). Given there remains a level of contestation around the creative industries notion in the literature, alongside recently emerging views which demonstrate difficulties in applying this form of analysis to non-urban locations, there remains further opportunities to explore these issues as they apply to creative workers in regional and rural locations, and in particular in relation to far north Queensland. Hence, given the lack of published research exploring the nature of the creative industries sector and creativity in Cairns, the key centre in far north Queensland, the following research question was developed: What might be revealed and understood in relation to creativity and the creative industries concept in terms of the tropical location of Cairns, Australia?

\section{Methods}

The philosophical approach or research paradigm adopted for this preliminary study was the interpretivist/constructivist framework (Mackenzie and Knipe 3), in order to develop a deep understanding of the issues facing those within the sector, as well as their perceptions relevant to Cairns' location, strengths and impediments. To achieve breadth, it was decided to initially develop an e-survey and administer this via the Surveymonkey platform, after which - and following an analysis of these initial data - interviews would occur to explore and explain further issues in depth. Thus, the research design was explanatory (Punch 296) where initial findings are explained and/or probed in follow-up research. While both approaches (esurvey, interviews) are potentially limited in terms of obtaining a comprehensive and detailed picture of all the issues, it was determined sufficient to at least begin to reveal a story about creativity and creative industries as applied to Cairns.

The survey was designed to explore a range of areas, including areas of creative practice, modes of employment, the role and relevance of government and strategic policy, as well as opportunities and challenges when looking to the future. The survey was distributed via a key 
representative arts organization to their email list of 292, with 88 responding to some parts of the survey and 78 finishing it completely, the latter representing a response rate of $27 \%$. In terms of the interviews, questions were designed to explore issues to emerge from the survey, including explanations relevant to a lack of engagement with public policy and/or strategy relevant to the creative industries, as well as further insights into the creative strengths and opportunities within the Cairns region. Indepth interviews were subsequently held with 20 individuals who had volunteered to participate after completing the survey and included creative practitioners, members of arts organisations and government workers, thus a relatively varied and representative sample.

\section{Findings}

\section{The Nature of the Sector and its Participants}

In terms of a broad picture of the activity that the survey respondents were engaged in, Table 1 below summarises gender and age factors, and then presents disciplines of practice, modes of employment, and identified roles or contributions within the sector, noting that respondents could select as many items as were relevant within each of the latter three areas. 
Table 1. Profiling the Cairns Creative Industries Survey Participants

\begin{tabular}{|c|c|c|c|c|c|c|}
\hline $\begin{array}{l}\text { Gender/age } \\
(\mathrm{N}=\mathbf{8 8})\end{array}$ & Area(s) of practice & $\begin{array}{l}\mathrm{N}=87 \\
(\%)\end{array}$ & $\begin{array}{l}\text { Mode(s) of } \\
\text { employment }\end{array}$ & $\begin{array}{l}\mathrm{N}=87 \\
(\%)\end{array}$ & $\begin{array}{l}\text { Identified role(s) and/or } \\
\text { contribution(s) to the } \\
\text { sector }\end{array}$ & $\begin{array}{l}\mathrm{N}=87 \\
(\%)\end{array}$ \\
\hline $\begin{array}{l}\text { Male: } 23(26 \%) \\
\text { Female: } 65(74 \%)\end{array}$ & Visual arts and crafts & $\begin{array}{l}60 \\
(69)\end{array}$ & $\begin{array}{l}\text { Freelance artist and/or } \\
\text { sole trader }\end{array}$ & $\begin{array}{l}58 \\
(67)\end{array}$ & $\begin{array}{l}\text { Provision of creative output } \\
\text { for public consumption }\end{array}$ & $50(60)$ \\
\hline \multirow{8}{*}{\begin{tabular}{|ll}
\multicolumn{2}{|l}{ Age brackets: } \\
$(6 \%)$ & $18-29: 5$ \\
$(14 \%)$ & \\
$(26 \%)$ & $40-49: 23$ \\
$(32 \%)$ & \\
$(23 \%)$ & \\
$(20-59: 28$ \\
$(23)$
\end{tabular}} & $\begin{array}{l}\text { Performing arts (music, } \\
\text { theatre, dance etc) }\end{array}$ & $\begin{array}{l}43 \\
(49)\end{array}$ & Volunteer & $\begin{array}{l}55 \\
(63)\end{array}$ & $\begin{array}{l}\text { Education and/or training in } \\
\text { the arts }\end{array}$ & $40(48)$ \\
\hline & $\begin{array}{l}\text { Event production, } \\
\text { management (festivals, } \\
\text { performances) }\end{array}$ & $\begin{array}{l}40 \\
(46)\end{array}$ & $\begin{array}{l}\text { Member of artist } \\
\text { collective/group }\end{array}$ & $\begin{array}{l}50 \\
(58)\end{array}$ & $\begin{array}{l}\text { Support services for artists } \\
\text { (e.g. admin) }\end{array}$ & $40(48)$ \\
\hline & Education \& training & $\begin{array}{l}39 \\
(45)\end{array}$ & Sole trader & $\begin{array}{l}45 \\
(52)\end{array}$ & $\begin{array}{l}\text { New forms of innovative } \\
\text { creative practice }\end{array}$ & $32(39)$ \\
\hline & Arts Administration & $\begin{array}{l}37 \\
(43)\end{array}$ & Government employee & $\begin{array}{l}41 \\
(47)\end{array}$ & $\begin{array}{l}\text { Provision of creative } \\
\text { products for customers or } \\
\text { clients }\end{array}$ & $31(37)$ \\
\hline & Advertising \& Media & $\begin{array}{l}30 \\
(34)\end{array}$ & Business owner & $\begin{array}{l}32 \\
(37)\end{array}$ & Artistic direction or curating & $29(35)$ \\
\hline & $\begin{array}{l}\text { Design (print, digital media, } \\
\text { web, architecture etc) }\end{array}$ & $\begin{array}{l}24 \\
(28)\end{array}$ & $\begin{array}{l}\text { Employee (private, } \\
\text { commercial) }\end{array}$ & $\begin{array}{l}27 \\
(31) \\
\end{array}$ & $\begin{array}{l}\text { Policy development in the } \\
\text { arts }\end{array}$ & $15(18)$ \\
\hline & Photography, Imaging & $\begin{array}{l}19 \\
(22)\end{array}$ & $\begin{array}{l}\text { Director/CEO/Manager } \\
\text { (government }\end{array}$ & $\begin{array}{l}12 \\
(14)\end{array}$ & $\begin{array}{l}\text { Preservation of artistic } \\
\text { heritage and/or products }\end{array}$ & $12(15)$ \\
\hline & Indigenous Arts & $\begin{array}{l}18 \\
(21)\end{array}$ & Apprentice/intern & $6(7)$ & & \\
\hline
\end{tabular}




\begin{tabular}{|c|c|}
\hline Video, Film & $\begin{array}{l}15 \\
(17)\end{array}$ \\
\hline Creative Writing & $\begin{array}{l}14 \\
(16)\end{array}$ \\
\hline Cultural Policy & $\begin{array}{l}14 \\
(16)\end{array}$ \\
\hline Museums, Heritage & $\begin{array}{l}10 \\
(12)\end{array}$ \\
\hline Fashion & $9(10)$ \\
\hline Computing \& Software & $3(3)$ \\
\hline
\end{tabular}


As can be seen in Table 1 above, the sample is mostly female and of a mature age. It also reflects the diversity typical of the creative industries sector, involving a range of forms of creative practice and employment, including those whose work is for cultural consumption (audiences) to others who aim to achieve significant commercial return from their creativity (clients). In addition, it highlights the fluid nature of employment practices, with a high percentage of freelance, sole trader and volunteer roles within the sector and in various combinations.

\section{Engagement with Public and Strategic Policy}

In order to explore the extent of engagement with public policy or strategic development documents, the survey respondents were asked to indicate their knowledge of five key documents, using a 5-point scale (1 - very little knowledge, 5 - extensive knowledge). The average ratings, in descending order, were as follows:

- Local council arts and cultural plan -2.85

- Arts Queensland cultural sector plan-2.62

- Cultural Tourism Strategy Tropical NQ - 2.30

- Australia council strategic directions plan -2.06

- Advanced Cairns economic plan - 2.06

These findings were one of the most surprising from the survey, given that none of these documents were known even moderately well on average, hence further explanation regarding this phenomenon was sought in the interviews. Some of the more telling included the following, and which reflect the range of views amongst the sample:

- I'm not interested in those (Photographer);

- It's bureaucratic talk and it's by marketing people. It's not visionary, strategic, long-term policy (New media artist);

- I'm not really sure because it's not really marketed much (Advertising designer);

- Basically not enough public information sessions. I don't know if that's due to a lack of interest from the community or a lack of push from people producing those policies (Theatre street performer);

- There is stuff out there. You've got to just look for it. It's not going to be in your face (3D artist); and

- Again, everything's lazy and it's mental laziness. Everybody wants somebody else to do it for them (Theatre performer).

Hence, these comments identify the challenges for policy and strategy makers in making such processes and outputs relevant and engaging for those in the sector, particularly those that are designed at state or national level. While there is arguably a responsibility of creative workers to engage with such documents to some extent, the low scores plus explanations presented in interviews proposes that there is much work to be done in this area. 


\section{Opportunities and Challenges in the Sector}

Survey respondents were asked to indicate what they believe are the future opportunities and challenges for the sector in Cairns. These are summarized below in descending order in terms of the number of times each item was selected, noting participants could select as many as they wished.

Table 2. Survey Respondents' Views on Opportunities and Challenges for the Creative Industries in Cairns

\begin{tabular}{|l|l|l|l|}
\hline Identified opportunities & $\begin{array}{l}\mathbf{N = 7 8} \\
(\%)\end{array}$ & Identified challenges & $\begin{array}{l}\mathbf{N = 7 8} \\
(\%)\end{array}$ \\
\hline $\begin{array}{l}\text { Increasing public engagement with } \\
\text { the arts }\end{array}$ & $59(76)$ & $\begin{array}{l}\text { Difficult economic } \\
\text { conditions and trends }\end{array}$ & $\begin{array}{l}51 \\
(65)\end{array}$ \\
\hline $\begin{array}{l}\text { Increasing public demand for } \\
\text { creative products and/or } \\
\text { experiences }\end{array}$ & $56(72)$ & $\begin{array}{l}\text { Increasing audiences and/or } \\
\text { market share }\end{array}$ & $\begin{array}{l}50 \\
(64)\end{array}$ \\
\hline $\begin{array}{l}\text { Developments in digital } \\
\text { technologies }\end{array}$ & $39(50)$ & $\begin{array}{l}\text { Accessing public or other } \\
\text { forms of funding support }\end{array}$ & $\begin{array}{l}46 \\
(59)\end{array}$ \\
\hline $\begin{array}{l}\text { Continued growth in social media } \\
\text { environments (e.g. facebook, } \\
\text { twitter) }\end{array}$ & $32(41)$ & $\begin{array}{l}\text { Sustaining viable long- } \\
\text { term career in the creative } \\
\text { industries }\end{array}$ & $\begin{array}{l}41 \\
(53)\end{array}$ \\
\hline $\begin{array}{l}\text { Increasing globalization and access } \\
\text { to new networks }\end{array}$ & $31(40)$ & $\begin{array}{l}\text { Accessing ongoing } \\
\text { opportunities for } \\
\text { professional development }\end{array}$ & $\begin{array}{l}34 \\
(44)\end{array}$ \\
\hline $\begin{array}{l}\text { The potential offered through the } \\
\text { National Broadband Network } \\
\text { (NBN) }\end{array}$ & $29(37)$ & $\begin{array}{l}\text { Keeping up to date with } \\
\text { changing technologies }\end{array}$ & $\begin{array}{l}25 \\
(32)\end{array}$ \\
\hline $\begin{array}{l}\text { The impending release of the } \\
\text { federal government's new National } \\
\text { Cultural Policy }\end{array}$ & $20(26)$ & $\begin{array}{l}\text { Accessing quality } \\
\text { employees or arts workers }\end{array}$ & $\begin{array}{l}20 \\
(26)\end{array}$ \\
\hline
\end{tabular}

As can be seen from Table 2 above, there is a correlation between the recognition that increasing audiences and engagement with creativity is a major opportunity, yet how to capture this potential also represents a significant challenge. The impact of relatively slow economic times in Cairns as a consequence of recent global financial issues is identified as the most significant concern, a factor largely compounded in Cairns by the impact of the seasonal tourism industry, with its peak in the JuneAugust period and relatively quiet periods either side of this time.

Creative Strengths and Impediments

In order to further explore issues associated with potential opportunities and challenges within the sector, interview questions were designed to explore what respondents felt were the creative strengths and impediments of the region. In terms of all responses, key terms were identified and wordles used to visualize the data, this method increasingly adopted as a valid tool in academic research (McNaught and Lam 630; Baralt, Pennestri and Selvandin 12). Figures 1 and 2 below present the key terms to emerge, with increasingly large words reflecting the number of times they were referenced by interviewees: 


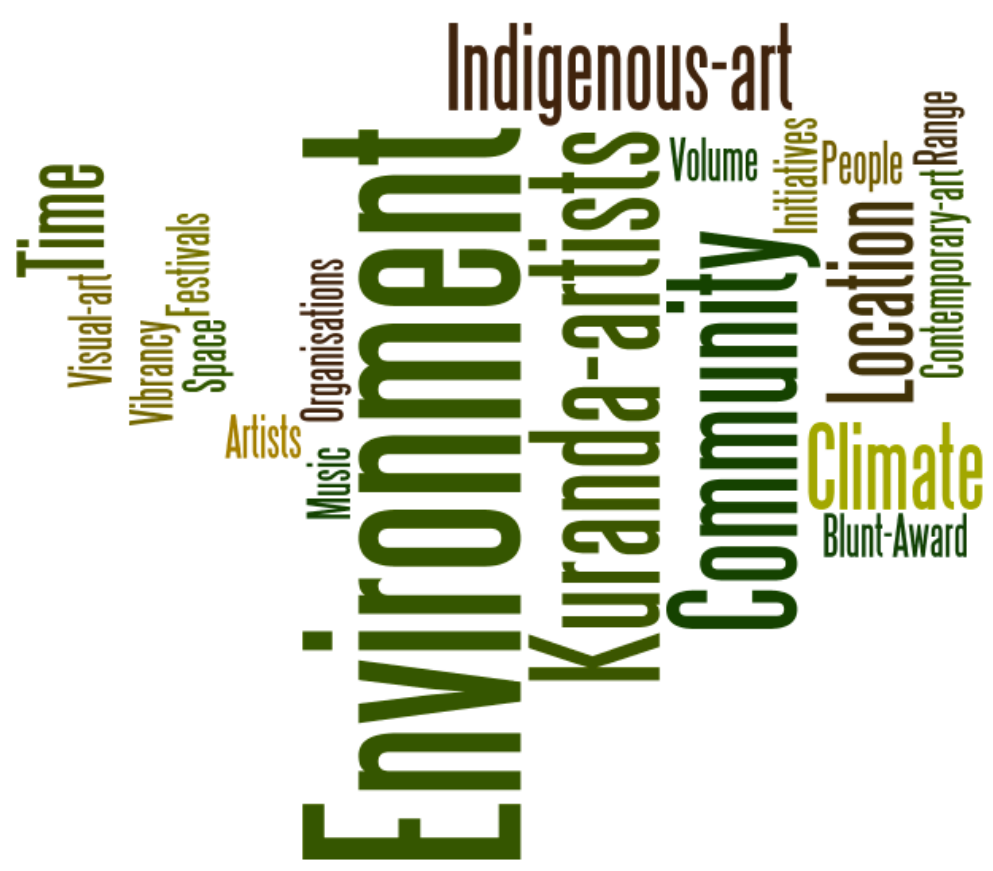

Figure 1. Creative Strengths of the Cairns Region

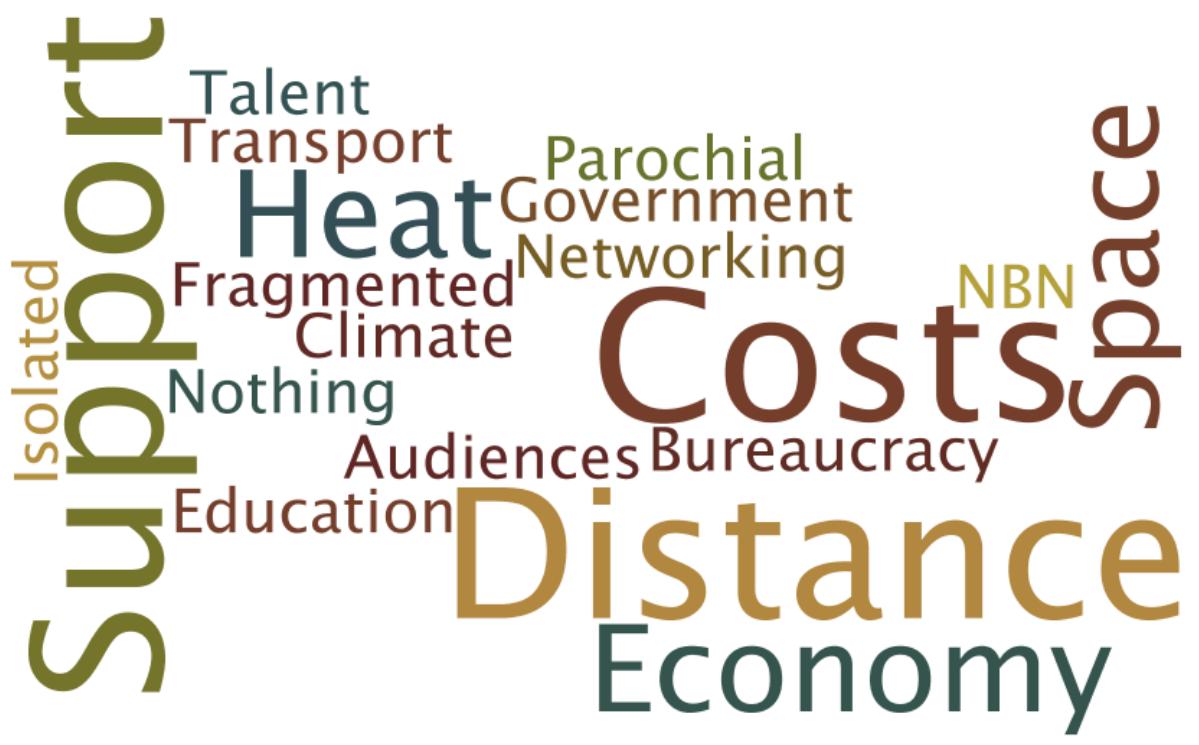

Figure 2. Impediments to Creativity in the Cairns Region

As can be seen in Figures 1 and 2, the location of Cairns and surrounds offers both significant strengths as well as challenges for creativity and creative workers. The location in the wet tropics and hence pristine natural environments is regarded as the dominant creative strength, yet it also results in a significant set of challenges due to the distance, costs (e.g. transport) and need for additional support (e.g. professional development, networking opportunities) to cater for this relative isolation. There is certainly a strong sense of community and of the significance of the indigenous artwork of the region and in such boutique locations as Kuranda, a small community 
25 kilometres north-west of Cairns and which houses many creative workers. Infrastructure issues remain an impediment for many, including access to spaces for creative practice, the delays and costs associated with the National Broadband Network (NBN), while there is also further reference to the cultural 'cringe' or parochialism that can occur in regional spaces and places.

\section{Discussion}

While the data obtained in this preliminary study is not statistically representative of the entire creative industries sector and workforce in Cairns, there are a number of key findings. Firstly, there is a very strong connection to the environment of Cairns, this reflecting the recent discourse and argument for the influence of and connection to place (Drake 511; Waitt and Gibson 1243; Luckman 2). Secondly, the data reveal the diversity of practice and artistic intent within the sector, with those working with clear commercial intent to those who seek to focus on presenting work for audiences and thus contributing to the cultural fabric of the city. This finding reflects the typical nature and diversity of the creative industries sector globally (Flew and Cunningham 113). At the same time, while this diversity offers variety and potential, it also requires that significant coordination and leadership is necessary in Cairns, given its relative isolation and potential impediments to creativity that this causes. The diversity and potential in Cairns is also impacted by seasonal in- and out-flows from the Tourism industry, which interviewees acknowledge has an affect on audiences and buyers of creative product.

Thirdly, it is clear that many sector participants have limited knowledge or engagement with key local, state and national arts/cultural or strategic planning documentation, and which reflects the criticism of the top-down focus of much creative and/or cultural industries policy (Gibson 3; Luckman 2). This could be due to the fact that many creatives see themselves divorced from mainstream activities, or traditional artists do not regard their work in a commercial sense. Based on the data obtained in interviews, it also reflects a disengagement between policy makers and practitioners on the ground, with many of the latter not seeing the relevance of such documents and strategies. Fourthly, the findings reveal that there are a number of growth strategies and partnerships with other industry sectors that have the potential to contribute further to the economic and cultural activity in Cairns. For example, there is significant potential for the creative sector to work more closely with Tourism, given the significance of the latter to the Cairns economy and potential contribution that visitors make to audiences and sales of cultural or creative product.

\section{Conclusion}

The data from this initial study exploring aspects of creativity and creative industries in Cairns reveals the fact that creative workers play a significant role in the cultural vitality and diversity of the city and the region. Survey and interview data revealed a cautious but optimistic view of the future for Cairns in terms of creative practice and creative industries. Therefore, further research is clearly necessary, in terms of the fractured relationship between creative workers and public policy and strategy, leadership of and cohesion within the sector, as well as the coordination and implementation of partnerships and other growth strategies. It is certainly clear that 
there is great potential for a vibrant tourist location like Cairns to grow its creative industries sector and play a stronger leadership role in the region. Indeed the achievement of viable and ongoing sustainable growth and productivity is both a key challenge and opportunity for all those involved.

\section{Works Cited}

Andersen, Lisa. "Magic Light, Silver City: the Business of Culture in Broken Hill" Australian Geographer 41.1 (2010): 71-85.

Anderson, Sallie. The Aboriginal Art Industry in Cairns, Queensland: An Ethnographic Study. Canberra: Australian National University, 2001.

Baralt, Melissa, Susan Pennestri, and Marie Selvandin. "Using Wordles to Teach Foreign Language Writing." Language, Learning \& Technology 15.2 (2011): $12-22$.

Brennan-Horley, Chris, Susan Luckman, Chris Gibson, and Julie Willoughby-Smith. "GIS, Ethnography, and Cultural Research: Putting Maps Back into Ethnographic Mapping." The Information Society: An International Journal 26.2 (2010): 92-103.

Brennan-Horley, Chris and Chris Gibson. "Where is Creativity in the City? Integrating Qualitative and GIS Methods." Environment and Planning A 41.11 (2009): 2595 - 2614.

Brennan-Horley, Chris, John Connell and Chris Gibson. "The Parkes Elvis Revival Festival: Economic Development and Contested Place Identities in Rural Australia." Geographical Research, 45 (2007): 71-84.

Cole, Malcolm. "Tropical Sounds: Music Learning and Teaching Within Cultures in Cairns and Yarrabah: 1930 to 1970.” E-Journal of Studies in Music Education 9.2 (2013): 44-63.

Cole, Malcolm. "Aspects of Indigenous Music Education in Yarrabah and Cairns: 1907 to 1966." In: Talking Back, Talking Forward: Journeys in Transforming Indigenous Educational Practice. Ed. Greg Williams. Darwin: Charles Darwin University Press, 2011. 178-185.

Cole, Malcolm. "Community Music Education in Cairns: 1920 to 1950." Magnetic Resonance and Research Conversations: Proceedings of the 2010 XXX XIInd and 2011 X X X IIIrd Annual ANZARME Conferences: Townsville: 3 - 6 July 2010 .

Collis, Christy, Emma Felton and Phil Graham. "Beyond the Inner City: Real and Imagined Places in Creative Place Policy and Practice." The Information Society: An International Journal 26.2 (2010): 104-112. 
Drake, Graham. "This Place Gives Me Space: Place and Creativity in the Creative Industries." Geoforum 34 (2003): 511-524.

Flew, Terry and Stuart Cunningham. "Creative Industries after the First Decade of Debate" The Information Society 26.2 (2010): 113-123.

Gibson, Chris (Ed.) Creativity in Peripheral Places: Redefining the Creative Industries. Abingdon, Oxon: Routledge, 2012.

Invest Cairns. Tourism. Available at <http://www.cairns.qld.gov.au/invest/research/industry-profiles/tourism>.

Kotkin, Joel. "Richard Florida Concedes the Limits of the Creative Class". Available at <http://www.thedailybeast.com/articles/2013/03/20/richard-floridaconcedes-the-limits-of-the-creative-class.html $>$.

Law, Lisa. "The Ghosts of White Australia: Excavating the Past(s) of Rusty's Market in Tropical Cairns." Continuum: Journal of Media \& Cultural Studies 25.5 (2011): 669-681.

Luckman, Susan, Chris Gibson and Tess Lea. "Mosquitoes in the Mix: How Transferable is Creative City Thinking?" Singapore Journal of Tropical Geography 30 (2009): 70-85.

Luckman, Susan. Locating Cultural Work: The Politics and Poetics of Rural, Regional and Remote Creativity. Basingstoke: Palgrave Macmillan, 2012.

Mackenzie, Noella and Sally Knipe. "Research Dilemmas: Paradigms, Methods and Methodology." Issues in Educational Research 16 (2006).

McNaught, Carmel and Paul Lam. "Using Wordle as a Supplementary Research Tool.” The Qualitative Report 15.3 (2010): 630.

Punch, Keith. Introduction to Research Methods in Education. London: Sage, 2009.

Verdich, Madeleine. "Creative Migration? The Attraction and Retention of the 'Creative Class' in Launceston, Tasmania." Australian Geographer 41.1 (2010): 129-140.

Waitt, Gordon and Chris Gibson. "Creative Small Cities: Rethinking the Creative Economy in Place." Urban Studies 46.5/6 (2009): 1223-1246.

Welters, Riccardo, Diana Castorina, Natalie Stoeckl and Ryan Daniel. "Has Townsville 'Come of Age'? Implications for Regional Policies.” Unpublished report commissioned by Townsville Enterprise Limited (2011).

Youdell, Rebecca. "Collective Future: JCU SoCA Cairns Consultation with the Creative and Cultural Sector." Unpublished report (2011). 